\title{
Novel surgical techniques, regenerative medicine, tissue engineering and innovative immunosuppression in kidney transplantation
}

\author{
Maciej Nowacki ${ }^{1,2}$, Łukasz Nazarewski ${ }^{3}$, Tomasz Kloskowski ${ }^{1}$, Dominik Tyloch ${ }^{1}$, \\ Marta Pokrywczyńska ${ }^{1}$, Katarzyna Pietkun ${ }^{1}$, Arkadiusz Jundziłt ${ }^{1}$, Janusz Tyloch ${ }^{1}$, Samy L. Habib ${ }^{4,5}$, \\ Tomasz Drewa ${ }^{1,6}$
}

\author{
${ }^{1}$ Chair of Urology, Department of Regenerative Medicine, Collegium Medicum \\ in Bydgoszcz, Nicolaus Copernicus University in Torun, Poland \\ ${ }^{2}$ Chair of Surgical Oncology, Collegium Medicum in Bydgoszcz, Nicolaus Copernicus \\ University in Torun, Poland \\ ${ }^{3}$ Department of General, Transplant and Liver Surgery, Medical University of Warsaw, \\ Warsaw, Poland \\ ${ }^{4}$ Department of Geriatrics, Geriatric Research, Education, and Clinical Center, South \\ Texas Veterans Healthcare System, San Antonio, TX, USA \\ ${ }^{5}$ Department of Cellular and Structural Biology, University of Texas Health Science \\ Center, San Antonio, TX, USA \\ ${ }^{6}$ Department of General and Oncological Urology, Nicolaus Copernicus Hospital, \\ Torun, Poland
}

Submitted: 1 November 2014

Accepted: 8 February 2015

Arch Med Sci 2016; 12, 5: 1158-1173

DOI: 10.5114/aoms.2016.61919

Copyright (c) 2016 Termedia \& Banach

\author{
Corresponding author: \\ Tomasz Kloskowski \\ Chair of Urology \\ Department of \\ Regenerative Medicine \\ Nicolaus Copernicus \\ University \\ Ludwik Rydygier \\ Collegium Medicum \\ 24 Karłowicza St \\ 85-092 Bydgoszcz, Poland \\ Phone: +48 525853823 \\ Fax: +48 525853956 \\ E-mail: tomaszkloskowski@ \\ op.pl
}

\begin{abstract}
On the $60^{\text {th }}$ anniversary of the first successfully performed renal transplantation, we summarize the historical, current and potential future status of kidney transplantation. We discuss three different aspects with a potential significant influence on kidney transplantation progress: the development of surgical techniques, the influence of regenerative medicine and tissue engineering, and changes in immunosuppression. We evaluate the standard open surgical procedures with modern techniques and compare them to less invasive videoscopic as well as robotic techniques. The role of tissue engineering and regenerative medicine as a potential method for future kidney regeneration or replacement and the interesting search for novel solutions in the field of immunosuppression will be discussed. After 60 years since the first successfully performed kidney transplantation, we can conclude that the greatest achievements are associated with the development of surgical techniques and with planned systemic immunosuppression.
\end{abstract}

Key words: kidney transplantation, novel surgical techniques, immunosuppression, regenerative medicine, tissue engineering.

\section{Introduction}

The first successful human kidney transplantation was performed by Joseph E. Murray, winner of a Nobel prize (in medicine and physiology, 1990), in 1954 [1, 2]. Dr Murray, who was later a Professor at Harvard and the Peter Bent Brigham Hospital, was not the first person historically to try to transplant a human renal allograft, but his crucial exploit paved the way for many further successes not only in the field of kid- 
ney replacement but also transplantation of other solid organs. The first kidney transplant in the 1950 s was also a very significant factor in creating the foundations for development of clinical transplantology, after a period of many setbacks and waiting for a great hope of a new unknown therapy form [3-5]. Historically, due to the attitude of knowledge and achievements of Murray, there were other great achievements such as the first liver transplantation performed by Thomas Starzl in 1963 and heart transplantation performed by Christian Barnard in 1967 [6-8]. The field of renal transplantation since 1954 has been significantly changed, especially in the surgical techniques and innovative operations. In addition, the introduction of novel techniques based on regenerative medicine and tissue engineering, as well as in patient care, is leading to elimination of the previously anticipated problems during transplant.

\section{Objective}

In the $60^{\text {th }}$ anniversary of the first successfully performed renal transplantation, we will present the historical, current and potential future status of kidney transplantation in selected aspects, based on a systemic overall analysis and literature review. We have previously discussed the following three aspects of kidney transplantation: development of surgical methods (1), the future of tissue engineered treatment procedures and perspectives to obtain a "bio-artificial" kidney (2) as well as analysis of the current status and future perspective of immunosuppression (3).

\section{The development of surgical methods}

\section{Background}

Historically, the kidney transplantation procedure has been largely performed via open nephrectomy, changing only slightly over the past 60 years [9]. This generally involves: the kidney being placed into the iliac fossa on the contralateral side of its origin; the renal vein anastomosed end-to-side with the external iliac vein; and ureterovesical anastomosis performed without anti-reflux surgery. This type of arterial anastomosis is the only area of dispute concerning the development of open procedures. For whilst most transplant centers carry out the procedure as described, there are some which anastomose the renal artery end-to-end with the internal iliac artery so as to enable easier and safer graftectomy in cases where septic bleeding occurs. Apart from this, the most significant development of surgical techniques and equipment has transpired in the field of living kidney donations, resulting in the implementation of laparoscopic and robot-assisted surgery [10-14].
The main pioneer of laparoscopy was Georg Kelling, who conducted celioscopy research on dogs, publishing his results in 1901 . Within this, he outlined the development of a diagnostic procedure for gastrointestinal bleeding whilst studying the potential therapeutic effects of high-pressure insufflations of air into the abdominal cavity, a technique which he called Luffttamponade. Also of significance is Hans Christian Jacobaeus, who reported on his experiences of laparothorascoscopy techniques in 1910, becoming the first to detail how he had performed laparoscopic surgery on humans in Sweden. This did much to popularize laparoscopy in the long term, with subsequent major breakthroughs not taking place until the 1980s. Most significant was the performance of the first laparoscopic appendectomy by the German gynecologist Kurt Semm in 1981, then the world's first cholecystectomy in 1985 by Erich Muhe, who used the same set of instruments as Semm. Following this, the development of laparoscopy accelerated rapidly [15-17].

Living-donor transplantation (LDN) has become the gold standard for the treatment of end-stage renal failure [18]. To minimize the procedure-related risk to a living donor, however, many techniques have been established besides open LDN (OLDN). After successful laparoscopic nephrectomies of kidneys in the early 1990s [19, 20], the first laparoscopic live donor nephrectomy (LLDN) was performed in 1995 by Lloyd Ratner and Louis Kavoussi at Johns Hopkins Bayview Medical Center [21]. From this, several approaches have developed either for OLDN (standard OLDN, miniOLDN) or for LLDN (pure LDN, hand-assisted LLDN - HALLDN). Such developments have been accompanied by new videoscopic techniques emerging with satisfactory results such as single-port LLDN, natural orifice transluminal endoscopic surgery (NOTES), laparoendoscopic single-site (LESS) and robotic LLDN.

Looking at these in more detail, two meta-analyses comparing OLDN and LLDN by Antcliffe et al. $[22,23]$ concluded that LLDN had no clear benefits over OLDN. For whilst there were shorter operative times using OLDN within random control trials, there were no significant differences in warm ischemia times. It was, however, found that Mini-OLDN ( $<15-\mathrm{cm}$ skin incision) had some advantages for the donor vs. standard OLDN with both shorter warm ischemia and operative times. Such measurements took into account the overall complication rate, postoperative analgesia, the total stay in hospital, and time taken off work. Prior to this, a review by Shokeir compared patient morbidity and mortality using OLDN versus LLDN, finding that the latter brought some disadvantages, including a rise in operative and warm 
ischemia times as well as an increase in major complications requiring reoperations [24]. Then, when comparing OLDN and HALLDN, laparoscopic techniques were favored with no significant differences found in renal function or allograft survival. For despite longer warm ischemia and operative times, HALLDN methods yielded better results in terms of postoperative donor pain, respiratory function and other recovery parameters $[25,26]$. At the same time, though, it was reported that laparoscopic surgery had increased the risk of intraoperative incidents, major complications and significant bleeding [27]. It is, nonetheless, expected that these high-grade complications of LLDN will decrease to the level of OLDN over time as its application is refined [28].

Besides these points, throughout the healing process, LLDN has cosmetic drawbacks, with three or four port incisions required over the single incision of OLDN (especially mini-OLDN) [29]. It is also far more expensive than OLDN, especially when it comes to postoperative complications [19, 30]. Overall, then, it seems that the adoption of laparoscopic techniques is more about shifting public opinion about live donors than replacing OLDN, especially as only a quarter of the general population are in favor of $\operatorname{LDN}[18,31]$. The availability of LLDN has been credited by the United Network for Organ Sharing (UNOS) as a factor driving a significant increase in LDN [32-34]. This is similar to observations made within the field of urology 10-15 years ago, where laparoscopic and open surgery started being performed in cases of prostate cancer [35]. In the future, it is proposed that these procedures be applied to kidney transplantations via the techniques described in Figure 1.

Ongoing efforts to improve laparoscopy have also benefited from the wider development of surgical robots. The first modern and innovate use of such machines came in 1985 when a robot, PUMA 560, was used by Kwoh et al. for a precision neurosurgical biopsy. Then in 1988, Davies et al. used the same machine to successfully perform a transurethral resection of a prostate. This use of robotics in surgery has continued to evolve since, particularly noticeably in the variety of devices which have been produced, such as PROBOT, ROBODOC, ARTEMIS, PRODOC, AESOP, ZEUS and, most recently, the da VINCI system (Intuitive Surgical, Mountain View, CA). Today, robotic surgery is mostly used for radical hysterectomies, prostatectomies, as well as colorectal and cardiothoracic surgery. Several published articles also describe the use of robotic surgery in gynecology, urology, general surgery and otolaryngology, with varying clinical effects [36-38].

In terms of general laparoscopic surgery, FDA approval for the use of the master-slave robotic surgical system da VINCI was granted in July 2000 [39]. Since then, numerous studies have correlated several advantages and achievements with the use of this device. Its application applies to two separate stages of the kidney transplantation process:

- Robotic donor nephrectomy/procurement (kidney removal from a living donor).

- Complete kidney replacement.

The first successful robot-assisted live-donor nephrectomy (referred to in the literature as RALD or RALDN for short) was performed via the da $\mathrm{VINCl}$ system in September 2000 by an operating team led by Professor Santiago Horgan from the Minimally Invasive Surgery Center and Division of Transplantation at the University of Illinois in Chicago. Meanwhile, the first robot-assisted kidney transplant was made using da $\mathrm{VINCI}$ again in June 2009 under the guidance of Dr. Stuart R. Geffner from the Division of Renal Transplantation in Livingston, New Jersey. A year later, in June 2010, came the first transplant in Europe, performed by Professor Ugo Boggi from the Division of General Surgery and Transplantation at the University Hospital of Pisa, Italy [40-44].

\section{The future}

As previously mentioned, the future development of open techniques is likely to focus on refining existing procedures, as has occurred in the last 60 years. The development of laparoscopic procedures correlates in the main with minor technical improvements or general advances in the medical learning curve. This is reflected in the focus of many publications on robotic surgery when discussing future developments in kidney transplantation surgery [45-48].

Robotic transplantation is a fairly recent development, employed in cases where there is a high risk of surgical site infections or when patients are morbidly obese, therapeutic effects being noted. Despite the fact that such innovations have been in use for a relatively short time, it has had a very dynamic effect, with positive results. A notable recent development in kidney transplantation surgery came in 2012 when Galvani et al. performed a single-incision robotic-assisted living donor nephrectomy. Another is when Kaouk et al. became the first group to perform a transvaginal hybrid natural orifice transluminal surgery robotic donor nephrectomy (Figure 2) [49-52]. More importantly, though, such revolutionary developments are seen by many as key to overcoming the obstacles posed by the small number of donors and organs which exist at present. Minimally invasive and associated with fewer complications, an increasing number of therapy units are offering this method of kidney transplantation, theo- 

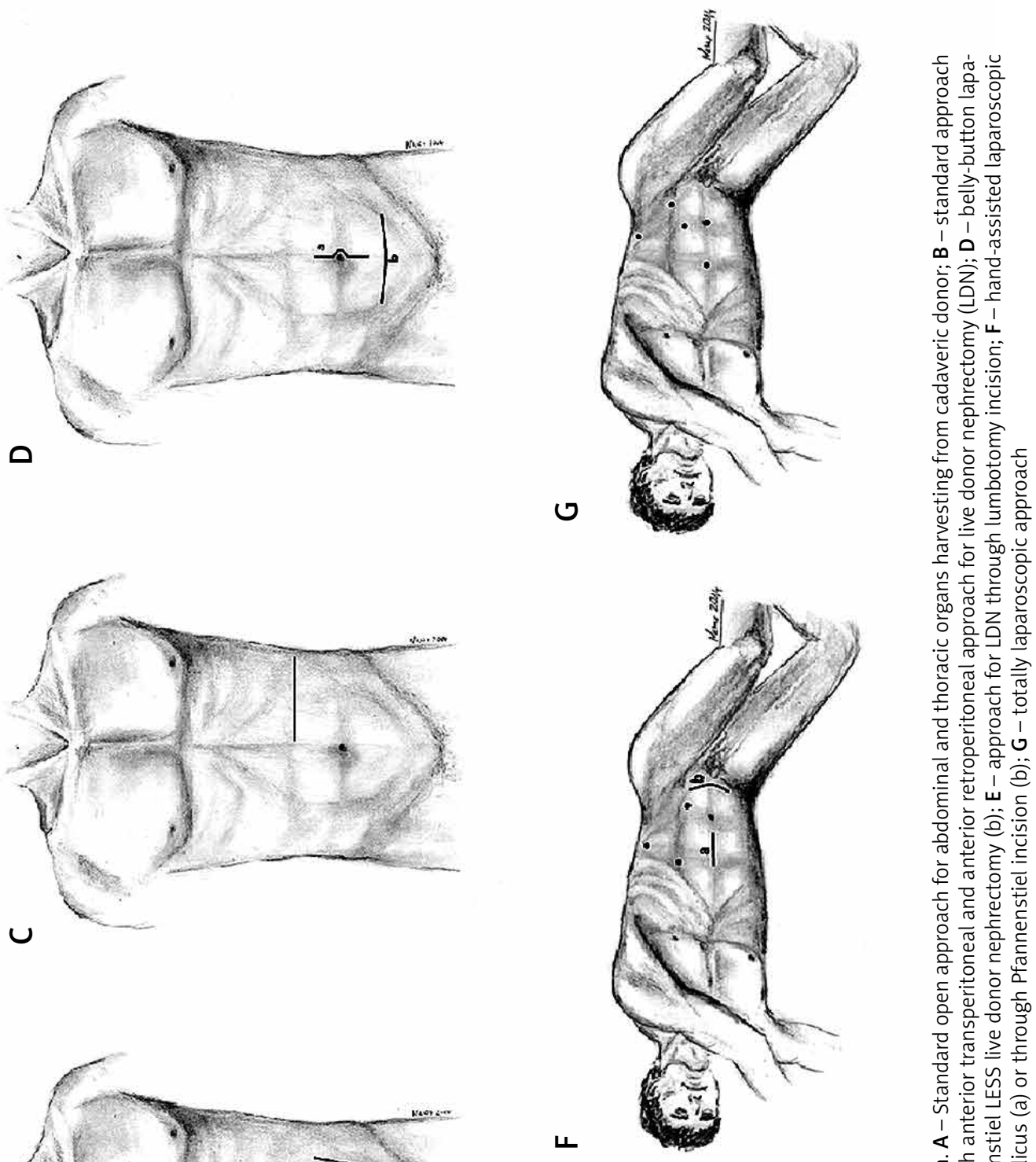

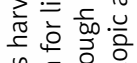

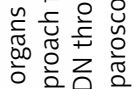

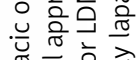

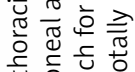

둥

ธั

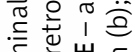

융 흠

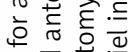

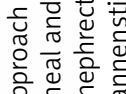

응ㅎํ

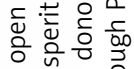

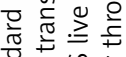

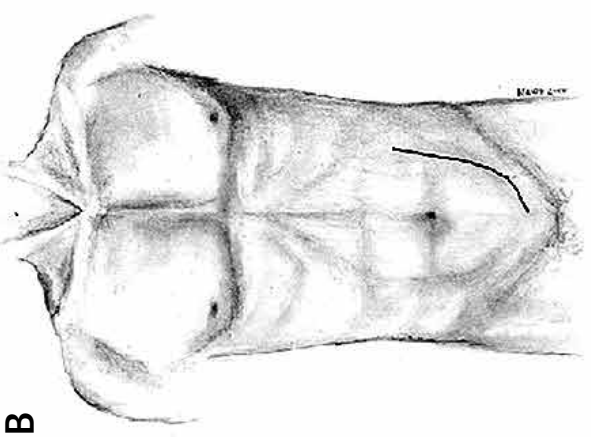

它.은 出

婇

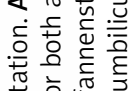

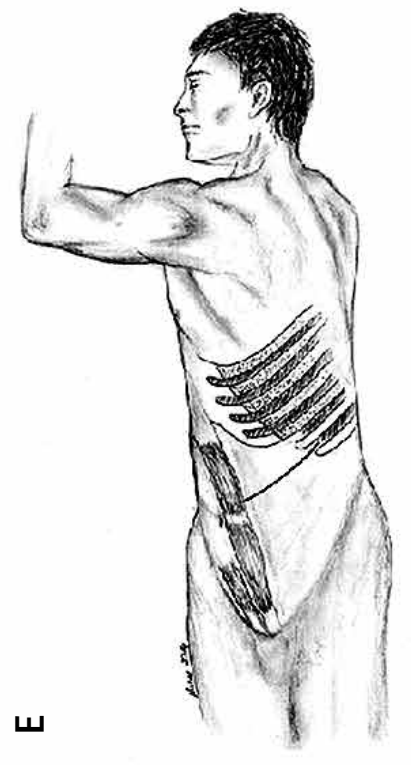

荧京贾

은.은 묻

霡

प्रे

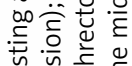

ఏ. 는

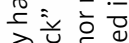

邓总施

产 衣? $\frac{0}{0}$

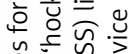

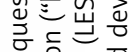

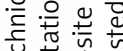

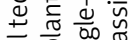

.

品

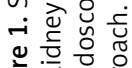

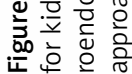

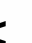


A

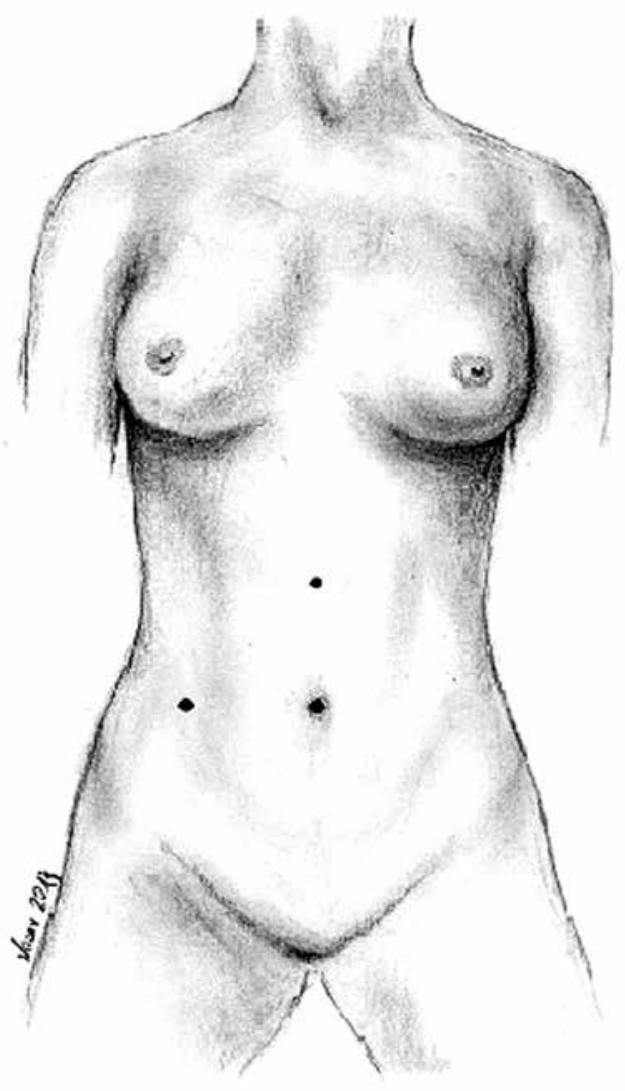

B

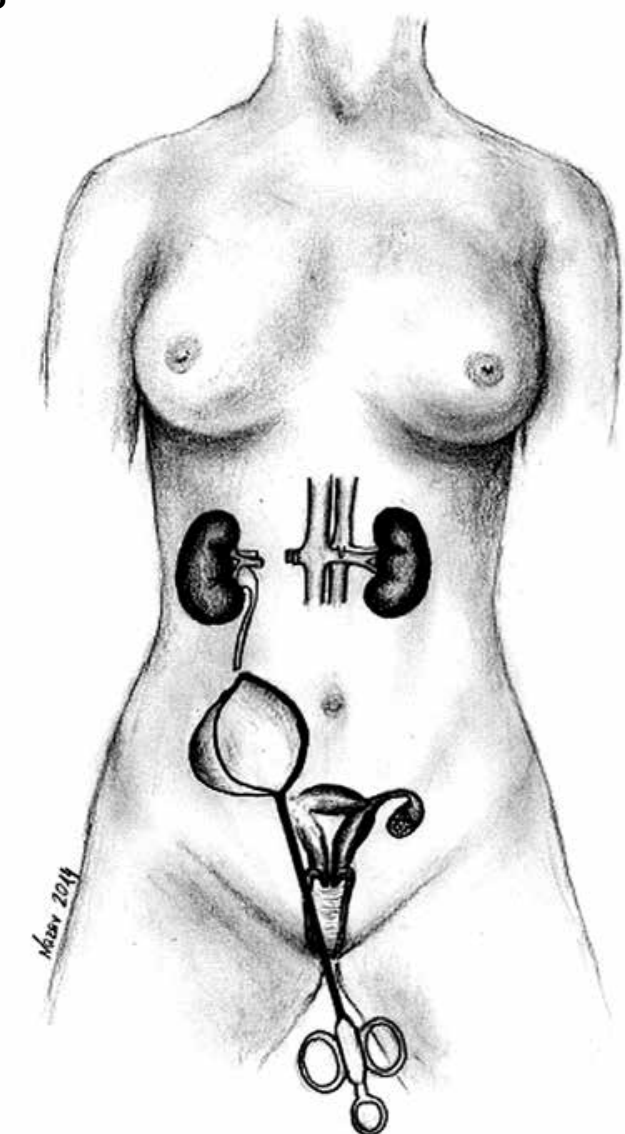

Figure 2. Techniques for living kidney donation in combined laparoscopic surgery. A - Proper placement of trocars, B - kidney removal in EndoBag through vagina

retically enabling more transplants in general and the possible growth of domino and cross transplants. In turn, a greater volume of living donors may be attracted to this "softer" form of kidney donation, with better cosmetic results and fewer potentially negative consequences compared to standard open and laparoscopic nephrectomies [53-55]. Other factors which indicate the growth of robotic systems in kidney transplantations are that it facilitates access to treatment for morbidly obese patients previously denied it as well as the development of innovative telemedicine procedures, where there is hope that transplants can be performed at distance [56-58].

Overall, though, the prevalence of robotic-assisted kidney transplantations is still low, with not enough fully objective data relating to the effectiveness of such treatments compared to other methods. At present, there are very few medical centers with the necessary equipment to undertake such a procedure, making it difficult to conduct randomized multi-center studies and meta-analyses. In addition, robotic procedures are expensive, at present offered by only one company, with a small number of medical specialists and literate professionals able to perform them [59-
61]. Alongside this, whilst robot-assisted surgery has the potential to decrease the duration of surgery, users who lack experience with such technology are likely to be operating for a substantially longer time than when adopting traditional and laparoscopic techniques. This difference is particularly noticeable when robotic methods are used for the first time $[41,62,63]$. All of this can have a significant impact given that time is a key factor in the success of a donor nephrectomy or kidney replacement, affecting the warm ischemia time and the possibility of reperfusion complications. This is probably the main reason why there is a higher documented number of robot-assisted living donor nephrectomies vs. fully performed replacement procedures.

Nonetheless, numerous examples involving animal models indicate that it is theoretically possible to improve operation times based on this technique. It is also important to stress that such concerns about robotic methods are based on a small number of scientific analyses and are greatly influenced by negative feedback from the US Food and Drug Administration (FDA) and the MAUDE (Manufacturer and User Facility Device Experience) database. These are largely concerned 
with the functioning of da $\mathrm{VINCl}$ in different surgical specialties and are not backed up by sufficient data [64-67]. In contrast, over 700 successful donor nephrectomies have been performed to date as well as more than 70 renal transplants, which have contributed to a reduced number of infections and other side risk factors correlated with standard open renal replacement. Furthermore, the growing number of robotic-assisted transplants will provide for a more extensive analysis of such procedures, better enabling many of the problems associated with such techniques to be overcome. This, it is hoped, will not only lead to more effective robotic kidney donor nephrectomies and kidney replacements but also have a significant impact on the development of kidney transplantations [53].

\section{Tissue engineering and regenerative medicine as kidney replacement therapy}

\section{Background}

In the future, tissue engineering and regenerative medicine may offer an alternative method of kidney regeneration and replacement. These two closely overlapping branches of science could provide a lot of new solutions, particularly in helping to meet the needs of organ recipients in a climate where there is a lack of organs and tissues available for transplantations [68]. From the published literature, four different methods of kidney reconstruction and regeneration using tissue engineering can be found: (1) the use of decellularized kidneys, (2) stem cell application, (3) therapeutic cloning and (4) bio-artificial kidney construction. First, there is the utilization of decellularized cadaveric kidneys, whereby scaffolds are seeded with cells to promote the regeneration of kidney tissue [69-71]. Significant progress has recently been made in this area by Song et al., who regenerated functional rat kidneys after decellularization through culturing epithelial and endothelial cells using a specially constructed scaffold within a whole-organ bioreactor [72]. Throughout this process, urine secretion was observed in vitro and in vivo through a urinary conduit after orthotropic transplantation.

Alternatively, kidneys can also be generated through the use of stem cells derived from another part of living tissue. Among the first innovations here has been the use of embryonic stem cells (ESCS), whose employment presents the advantage of allowing the creation of 3D structures which resemble kidneys without the use of scaffolding, such totipotential cells being able to differentiate into renal cells such as tubules and podocytes [73-75]. Disadvantages, however, center not only around ethical concerns but also the possibility of teratoma formation [76, 77]. As a result, research has focused more on differentiated autologous stem cells such as bone marrow derived from mesenchymal stem cells (MSCs), adipose derived stem cells (ADSCs), or amniotic fluid stem cells (AFSCs). Such cells offer the benefit that they can be isolated using minimally invasive procedures whilst also having the ability to differentiate into renal cell lines via variant growth factors or conditioned media [78-80]. For instance, cloned metanephroi derived from adult cow fibroblast can be seeded in unwoven polyglycolic acid sheets to successfully create a kidney-like structure which can then be transplanted into the same cow for between 6 and 12 weeks, during which time it is able to discharge a urine-like fluid [81].

Differing from these approaches is the creation of bioartificial kidneys (BAKs), such constructions being able to support or replace the natural filtration process of the kidney. These are formed from material such as hollow fibers and cells (mainly renal) [82-87], clinical studies on an admittedly small number of patients indicating that this is a very promising way of treating acute renal failure. Nonetheless, results so far have yielded insufficient success, with experimental treatment using BAK only being able to be maintained for $24 \mathrm{~h}$ [82].

\section{The future}

Complete kidney regeneration using tissue-engineering methods is still at an experimental stage $[84,88]$. Problems remain developing BAK-based treatments which can be used safely on all patients who qualify for renal replacement. Not only are there issues of a technical nature and about "bio-compatibility" but also there is a lack of both knowledge and available bio-technical solutions at present to create a device which can fully replace as physiologically complex an organ as the kidney [89]. All of this means that stem cells, for the restoration of renal function, are likely to feature more prominently in short-term developments as opposed to the implementation of novel BAK systems [90-92]. This is a conclusion borne out by the existing published data, analyses of current studies and general sentiment, not to mention the growing number of stem cell procedures being performed in other medical fields [93-96].

Here, an increasing number of such studies can be observed at ClinicalTrial.gov (Table I). Driving this is a well-established isolation and cultivation technique to extract MSCs from bone marrow as well as adipose tissue. In all registered trials, isolated MSCs are administered intravenously, a procedure which is also simple to perform. Other approaches such as the deployment of a decellularized kidney or constructing a bio-artificial kidney present much greater technical challenges. 
Table I. Registered studies at ClinicalTrials.gov using mesenchymal stem cell transplantation in patients for kidney regeneration

\begin{tabular}{|c|c|c|c|}
\hline Type of study and number & Reason & Cell type & $\begin{array}{l}\text { Estimated } \\
\text { enrollment }\end{array}$ \\
\hline $\begin{array}{l}\text { An open-label, non-randomized, multi-center study } \\
\text { phase } 1-2 \text { trial } \\
\text { (NCT01453816) }\end{array}$ & CKD & Autologous ADSC & 10 \\
\hline $\begin{array}{l}\text { Single-center, open-label phase } 1 \text { trial } \\
\text { (NCT02195323) }\end{array}$ & CKD & Autologous BM-MSC & 10 \\
\hline $\begin{array}{l}\text { Single-center, open-label phase } 1-2 \text { trial } \\
\text { (NCT00659620) }\end{array}$ & $\begin{array}{l}\text { Chronic allograft } \\
\text { nephropathy }\end{array}$ & MSC & 20 \\
\hline $\begin{array}{l}\text { Single-center, open-label phase } 1 \text { trial } \\
\text { (NCT01840540) }\end{array}$ & $\begin{array}{l}\text { Atherosclerotic renal } \\
\text { artery stenosis }\end{array}$ & Autologous ADSC & 6 \\
\hline $\begin{array}{l}\text { Single-center, open-label phase } 1 \text { trial } \\
\text { (NCT02166489) }\end{array}$ & CKD & Autologous BM-MSC & 6 \\
\hline $\begin{array}{l}\text { Non-randomized, open-label phase } 1 \text { trial } \\
\text { (NCT00733876) }\end{array}$ & AKI & Allogenic BM-MSC & 15 \\
\hline $\begin{array}{l}\text { Single-centre, open-label phase } 1 \text { trial } \\
\text { (NCT01275612) }\end{array}$ & AKI & Allogenic BM-MSC & 9 \\
\hline $\begin{array}{l}\text { Randomized, multicenter, double-blind, placebo- } \\
\text { controlled phase } 2 \text { trial } \\
\text { (NCT01602328) }\end{array}$ & AKI & Allogenic BM-MSC & 156 \\
\hline
\end{tabular}

This explains why studies using these latter methods are still at an early stage of development (in vitro and animal studies). Similarly, the first clinical study of de novo kidney regeneration will require more time [97-102].

\section{Immunosuppression and patient care}

\section{Background}

The immune system can cause significant problems in terms of the acute and chronic rejection of kidney transplantations [103, 104]. These complications have resulted in a constant search for new ways to reduce the likelihood of such outcomes $[105,106]$. One of the pioneers of immunosuppression is Jean Hamburger, who used total body irradiation to prevent the rejection of transplants. He discovered this method of preventing rejection after the accidental irradiation of six Yugoslav researchers who survived bone marrow graft surgery. This marked the beginning of scientific attempts to influence the immune system, allowing future successful organ transplants [107, 108]. Hamburger was also the first to note the morphological changes which take place in rejected organs via transplant biopsies. However, whilst total body irradiation produced the desired effect on the immune system, its many adverse effects resulted in attempts to limit the irradiated area, be it to the localized area of the transplant, the thymus or the blood $[109,110]$.

Attempts were also made in the field of pharmacology to discover a means of chemical immu- nosuppression to either complement or completely replace irradiation. Experimenting on rabbits, Schwartz and Dameshek concluded that 6-mercaptopurine offered promise as an agent of antibody reduction, the drug subsequently being used as a cytostatic agent in the treatment of neoplastic diseases. Then there was the introduction of azathioprine - a prodrug synthesized by George Hitchings and Gertrude Elion in 1957 which substitutes for normal metabolites through purine synthesis of DNA and RNA - to transplantology by Sir Roy Calne [111-113]. This proved particularly effective when combined with glucocorticoids by Thomas Earl Starzl in 1963, marking the beginning of combined therapy. Since then, though, cyclosporine and mycophenolate mofetil have replaced these drugs in transplant procedures, azathioprine having a number of adverse effects such as hepatotoxicity and myelotoxicity (suppression of bone marrow) as well as biliary and vascular complications [114, 115].

In particular, cyclosporine, a calcineurin inhibitor (CNI) isolated from the Norwegian fungus Tolypocladium inflatum, has become a widely used immunosuppressive agent [116, 117]. Its effect lies in inhibiting the release of interleukins which, in turn, inhibit the differentiation of lymphocytes, significantly improving the results of organ transplantations in general. Among its unwanted side-effects are nephrotoxicity (leading to late allograft loss), thrombotic microangiopathy, anemia and thrombocytopenia. This has led to the development of alternatives, the most recent being 
tacrolimus, which, whilst having a stronger effect, is associated with more complications, especially in cases of diabetes, and may lead to posterior reversible encephalopathy syndrome (PRES). This complication, first described in 1996, mainly manifests itself in headaches, confusion, visual loss and seizures, showing the visual characteristics of cerebral edema [118, 119].

Overall, though, CNIs are currently used in 95\% of post-transplant immunosuppressive therapy in the US. In the case of cyclosporine, its concentration in the blood needs to be maintained to prevent transplant rejection and to reduce its nephrotoxicity, hepatotoxicity and negative impact on the cardiovascular system [120, 121]. Meanwhile, mycophenolate mofetil, first used in 1995, acts by inhibiting inosine monophosphate dehydrogenase (IMPDH) and purine synthesis whilst preventing the division of lymphocytes. When combined with cyclosporine and steroids, it has also been proven to reduce the occurrence of acute rejection during transplants, increasingly substituting for azathioprine in surgical procedures. Nonetheless, it is not without drawbacks, being linked with complications such as gastrointestinal problems, leucopenia and opportunistic infections [122, 123].

Immunosuppressive drugs also act to inhibit cell proliferation by blocking the mammalian target of rapamycin (mTOR), a serine/threonine protein kinase. One of the agents in this group is sirolimus (rapamycin), a macrolide lactone produced by the actinomycete bacterium Streptomyces hygroscopicus [124]. Comparing its side effects to cyclosporine, there are fewer occurrences of wound healing disturbances as well as less adverse effects on lymphocytes and the hematological system. Conversely, it has been found more often to cause nephrotoxicity and hypertension. As a result, sirolimus should not be used in the days immediately following a kidney transplantation, its value coming later in the recovery process as a substitute for calcineurin inhibitors, particularly in allograft nephropathy $[125,126]$. At present, immunosuppressive therapy in the aftermath of a kidney transplantation relies on the use of tacrolimus and cyclosporine $A$ to perform the role of calcineurin inhibitors, alongside mycophenolate mofetil and glucocorticoids, which act as maintenance agents [127-129].

Alongside these methods of immunosuppression has been the removal of $T$ lymphocytes using polyclonal antibodies obtained through the immunization of animals. This has proved to be particularly useful in cases of acute kidney rejection whilst minimizing risk levels. Further advances have also been made with the employment of monoclonal antibodies and OKT3 against the lymphocytes of transplant recipients [130, 131]. At present, though, the application of immunoglobulin is most prevalent as a means of inducing immunosuppression, as well as being used to overcome acute rejection and to reduce the prevalence of alloantibodies as part of the desensitization process. Rituximab, a monoclonal antibody against CD20 which limits the activity of B cells and antibody production, has also been applied during desensitization, and its use in ABO-incompatible transplantations has delivered promising results. Meanwhile, other treatments of acute rejection and induction therapy include daclizumab, a humanized monoclonal antibody, and basiliximab, a chimeric mouse-human monoclonal antibody. Both act as IL-2 receptor antagonists and have the advantage of rarely causing side effects with no increased incidence of infections [132-135].

Such new immunosuppressive regimens have made $\mathrm{ABO}$-incompatible kidney transplantation possible, increasing the pool of potential donors. This is achieved by desensitization in both pre-transplant therapy and as part of treatment in end-stage renal disease $[136,137]$. Allied to this, it is important to remember the significant role that post-surgery procedures play in the longterm success of kidney transplants. These require specific problems related to individual patients to be taken into account, whereby it is necessary that medical staff are able to recognize the initial symptoms of complications and to take the necessary preventative measures - all of which requires adherence to international guidelines which have evolved in line with developments in the field of kidney transplantation. One of their major aims is to reduce the risk of death from cardiovascular diseases, malignancy and infection and graft rejection, education having a significant role to play in continuing to improve the lives of those who undergo such treatment $[138,139]$.

Another important issue to consider is the appropriate matching of donors and recipients. Initially, people were matched only by their blood groups before recipients were also administered with sera and lymphocytes from the donor. Subsequently, bringing developments to the present day, human leukocyte antigens (HLA) have become the core of donor-recipient matching, the most significant being A, B and DR proteins of HLA $[140,141]$. With the final assessment made on the basis of a points system, the absolute contraindications for kidney donation include malignancies, the presence of HIV, hepatitis B and C, sepsis and an increase in creatinine. In the case of the recipients, they are: serious liver failure, serious cardiovascular disease and AIDS. Meanwhile, if a patient has suffered from cancer previously, it is necessary to postpone surgery, particularly given that there is a generally greater risk of developing malignan- 
cies after kidney transplantation. Among the most common cancers in those who have undergone transplants are Kaposi's sarcoma, vaginal cancer, non-Hodgkin lymphoma, kidney cancer, non-melanoma skin cancer, lip cancer, thyroid cancer and small intestine cancer [142].

Throughout this, the screening process requires that each patient be considered on a case-by-case basis, taking into account family history, tobacco use and other factors which increase the risk of death, for the aftermath of the transplantation treatment may trigger a number of adverse health effects. Though often associated with kidney disease beforehand, hypertension can be brought on by immunosuppressive treatment, prednisone being associated with renal artery stenosis and graft dysfunction. Moreover, increased glucose levels are very common and have a negative impact on patient and graft survival, being defined by the World Health Organization as new-onset diabetes after transplantation (NODAT) [143, 144]. Obesity is another problem which requires patients have their body mass index (BMI) monitored during post-transplant follow-up visits, abnormalities best dealt with via lifestyle modifications which promote greater health more generally [145]. Among other methods to combat hypertension, there is no preferred agent of treatment, though some researchers have suggested that calcium channel blockers could be beneficial in limiting graft channels [146], except for patients with proteinuria, for whom ACE-I and ARB are preferred. Overall, though, combination therapies are considered most effective in spite of administered drugs possibly resulting in hypercalcemia, hyponatremia, hyperuricemia and hyperglycemia. This is especially true among high-risk patients.

\section{The future}

Guiding attempts to improve current immunosuppression methods is a concern to prolong the period in which grafts and patients survive. Calcineurin inhibitors, antiproliferative agents and antibody induction agents have significantly reduced the probability of acute rejection, and patient and graft survival rates in the year after kidney transplantations are presently excellent. Nonetheless, there are various side effects due to the nephrotoxic long-term effect of immunosuppressive therapy in its present form. Therefore, different ways of inhibiting lymphocyte activation need to be explored [147]. In Table II, there is a summary of all the information about the various agents which have been used recently [148-164]. In future, treatments using immunoglobulin may play a greater role in the prevention of transplant rejection, because it allows more precise and effective therapy whilst possessing fewer long-term side effects, welcome news in attempts to address what is a fundamental problem in renal transplantations.

On the issue of problems, an increasingly common one regards immunosuppression among HIV-positive patients. Nephropathy is one of the complications experienced by this group, and it is a recurring cause of end-stage renal failure. Despite this, kidney transplantation is considered safe at present among correctly selected patients of this type, short-term results proving similar to those observed in cases of uninfected recipients. Moreover, it has been proven that some immunosuppressive drugs benefit from antiretroviral treatment [165-167]. One completely revolutionary way to achieve immunosuppression after surgery is based on a kidney transplant being combined with a simultaneous transplantation of stem cells. This is designed to induce donor-specific tolerance in patients, potentially preventing allograft rejection. Several experiments on animals demonstrate this with drug-free survival possible through a stable mixed chimerism [168]. In such a case, the recipient becomes a chimera after the implantation of stem cells, possessing at least two different populations of genetically distinct cells.

Even so, a study by Seifert and her colleagues revealed increased inflammation in the aftermath of donor-type MSCs being administered [169]. Their study also showed no increase in graft survival or signs of partial tolerance being developed. At the same time, research conducted by Duojiao Wu illustrated a potential method to induce immunologic tolerance, showing that lipoprotein metabolism and plasma levels of fibrinogen play a role in hematopoietic stem cells (HSCs) inducing immunologic tolerance as well as acute rejection [170]. From this it was concluded that the molecular influence of HSC transplants on the immune system is a new area to explore in immunosuppression, given that it could help address adverse effects associated with current techniques. In addition, Tatsuo Kawai also observed that stable graft function may be achieved after the complete withdrawal of immunosuppressive drugs in mismatched HLA grafts where kidney transplantations are combined with bone marrow transplants [171].

More successfully completed clinical trials are detailed in "Science Translational Medicine" by Joseph Leventhal and Suzanne T. Ildstad as part of an article entitled "Chimerism and Tolerance Without GVHD or Engraftment Syndrome in HLA-Mismatched Combined Kidney and Hematopoietic Stem Cell Transplantation". Here, kidney transplantations are preceded by gathering a donor's marrow stem cells and then subjecting them to the appropriate recipient [172]. Positive results were also obtained by Jianming Tan, who noted a lower incidence of acute rejection in 
Table II. Selected immunosuppressive agents investigated in recent years

\begin{tabular}{|c|c|c|c|}
\hline Agent & Availability & Influence & Characteristics \\
\hline Voclosporin & $\begin{array}{l}\text { Experimental - not } \\
\text { FDA approved [148] }\end{array}$ & $\begin{array}{l}\text { Action against } \\
\text { calcineurin } \\
\text { - Analog of } \\
\text { ciclosporin }\end{array}$ & $\begin{array}{l}\text { - Studies on nonhuman primate model comparing it } \\
\text { with cyclosporine showed significantly longer sur- } \\
\text { vival of allografts treated with voclosporin though } \\
\text { its serum levels were lower and adverse effect fewer }\end{array}$ \\
\hline Sotrastaurin & $\begin{array}{l}\text { Discontinued } \\
\text { investigation }[149,150]\end{array}$ & $\begin{array}{l}\text { Protein kinase C } \\
\text { inhibitor }\end{array}$ & $\begin{array}{l}\text { - Prolongs survival of life-supporting kidney al- } \\
\text { lografts in non-human primate recipients both as } \\
\text { a monotherapy and with combination with CsA } \\
\text { - Studies showed increased incidence of acute re- } \\
\text { jection, graft loss and death }\end{array}$ \\
\hline Belatacept & $\begin{array}{l}\text { Approved by the } \\
\text { U.S. Food and Drug } \\
\text { Administration } \\
\text { in } 2011 \text { for } \\
\text { use in kidney } \\
\text { transplantation } \\
\text { [151-153] }\end{array}$ & $\begin{array}{l}\text { Protein consisting of } \\
\text { extracellular domain } \\
\text { of CTLA-4 linked to } \\
\text { the Fc fragment of } \\
\text { human Ig }\end{array}$ & $\begin{array}{l}\text { - Incidence of acute rejection is higher in belatacept } \\
\text { than in cyclosporine group } \\
\text { - Described as "first new agent available in kidney } \\
\text { transplantation that achieves the goal of improved } \\
\text { long-term renal function" } \\
\text { - Lower blood pressure, lower non-HDL lipids, appro- } \\
\text { priate GFR, may improve long-term graft survival } \\
\text { in CNI free immune therapy }\end{array}$ \\
\hline Tofacitinib & $\begin{array}{c}\text { Approved by } \\
\text { Food and Drug } \\
\text { Administration in } \\
2012 \text { for treatment of } \\
\text { rheumatoid arthritis } \\
\text { Tofacitinib } \\
\text { development has } \\
\text { been discontinued } \\
\text { in kidney } \\
\text { transplantation } \\
\text { [154, 155] }\end{array}$ & $\begin{array}{l}\text { Inhibitor of JAK } \\
\text { kinase }\end{array}$ & $\begin{array}{l}\text { - Pre-clinical studies on kidney transplantation } \\
\text { which showed the elongation of graft survival clin- } \\
\text { ical trials showed a similar extent of prevention of } \\
\text { acute rejection compared to cyclosporine } \\
\text { - Compared to cyclosporine renal function was im- } \\
\text { proved and occurrence of post-transplant diabetes } \\
\text { was reduced } \\
\text { - Increased risk of viral infection, anemia and leuko- } \\
\text { penia, and lymphoproliferative disorder }\end{array}$ \\
\hline Alefacept & $\begin{array}{l}\text { Withdrawn from the } \\
\text { market in } 2011 \text { [156] }\end{array}$ & $\begin{array}{l}\text { Protein consists of } \\
\text { LFA3/IgG1- reduces } \\
\text { the number of } \\
\text { memory T cells }\end{array}$ & $\begin{array}{l}\text { - Incidence of malignancy was higher in alefacept } \\
\text { group }\end{array}$ \\
\hline Efalizumab & $\begin{array}{l}\text { Suspended from } \\
\text { the market in } 2009 \\
{[157-159]}\end{array}$ & $\begin{array}{l}\text { Binds to CD11a - } \\
\text { inhibiting lymphocyte } \\
\text { activation and cell } \\
\text { migration }\end{array}$ & $\begin{array}{l}\text { - Side effect (bacterial sepsis, invasive fungal dis- } \\
\text { ease and progressive multifocal leukoencephalop- } \\
\text { athy }(\mathrm{PML}) \text { ) }\end{array}$ \\
\hline Eculizumab & $\begin{array}{l}\text { Approved by the } \\
\text { United States } \\
\text { Food and Drug } \\
\text { Administration } \\
\text { (FDA) in } 2007 \text { for } \\
\text { the treatment of } \\
\text { paroxysmal nocturnal } \\
\text { hemoglobinuria } \\
\text { (PNH) and atypical } \\
\text { hemolytic uremic } \\
\text { syndrome [160-162] }\end{array}$ & $\begin{array}{l}\text { Recombinant } \\
\text { humanized } \\
\text { monoclonal lgG } 2 / 4 \\
\text { antibody - binds } \\
\text { to the complement } \\
\text { component } 5 \\
\text { and blocks the } \\
\text { activation of terminal } \\
\text { complement }\end{array}$ & $\begin{array}{l}\text { - Reduces antibodies in highly sensitized patients } \\
\text { and in prevention of antibody mediated rejection } \\
\text { in a case series } \\
\text { - Investigated in an ABO-incompatible kidney trans- } \\
\text { plantation }\end{array}$ \\
\hline Bortezomib & $\begin{array}{l}\text { Approved for multiple } \\
\text { myeloma in the } \\
\text { United States in } 2010 \\
\quad[163,164]\end{array}$ & Binds proteasome & $\begin{array}{l}\text { - Case series confirmed to remove HLA antibodies in } \\
\text { live-donor transplant recipients and to treat anti- } \\
\text { body acute rejection }\end{array}$ \\
\hline
\end{tabular}

therapy using autologous MSCs than that found in induction treatment employing an anti-IL-2 receptor antibody [173]. Moreover, during the study, a decreased risk of opportunistic infection was observed along with better renal functionality. In particular, a study of 6 patients assigned to Reinders raised the possibility of treating allograft rejection after renal transplantation using autologous bone marrow-derived mesenchymal stromal cells. Proceeding from here, the therapy is, on the one hand, considered feasible with high levels of tolerance noted. Yet, on the other hand, attention is drawn to systemic immune suppression demonstrated by the incidence of viral infections [174]. 


\section{Conclusions and summary}

Overall, reflecting on the development of surgical methods, there is a great deal of innovation present, with modern techniques playing a significant and increasing role in a large number of transplantation centers. This has generally centered around the displacement of standard open-surgery techniques in favor of novel laparoscopic and, to a lesser extent, innovative robotic procedures, particularly in centers with a high level of specialization. Unfortunately though, having studied all the relevant literature, this trend is unevenly spread, failing to reach smaller local centers with less qualified personnel. One of the main factors behind this is that novel treatment procedures such as robotic surgery or modern laparoscopy require a high level of investment. This is not only in terms of the initial capital outlay needed for the necessary operating devices but also in terms of expensive ongoing maintenance costs, the purchase of supporting tools and accessories, as well as expenditure on professional training for all surgeons and their assistants. Nonetheless, in spite of these issues, it is encouraging to see the increasing prevalence of more modern techniques in general, notably those used in the example of obese patients.

Meanwhile, advances in immunosuppression, which historically "opened the door" for successful transplantations to occur, continue to evolve. Not only have techniques become more efficient, they have also become fully "tailored" to each individual patient's medical requirements. Developments such as the implementation of novel methods to induce immunologic tolerance have made it possible to offer new solutions in the field. Among them, the "most developmental" has been the use of cyclosporine, which has allowed transplantations to be performed on a large scale. To unlock more opportunities, though, further increases in knowledge of the human immune system are needed to be able to influence it in a more targeted way, stem cell therapy and chimerism being possible areas of exploration. Such advances would give hope that immunosuppressive therapy can be performed with fewer complications in future and that transplants will no longer require chronic treatment in this regard.

It is also important to highlight that the development of transplant surgery and immunosuppression medicine has been aided by the birth of two new biomedical disciplines of life science in tissue engineering and regenerative medicine. Analyzing the published materials, it has been observed that a large number of scientists have focused their investigations on new cell-based therapies and ways to construct bio-artificial organs which could be potentially used in clinical transplantology. Within this field, much of the published data show that there are many obstacles to developing an effective and fully applicable bio-artificial kidney, and it is highly unlikely that a revolutionary discovery will be made in the near future. By contrast, the use of novel stem cell therapies or stem cell based supportive procedures offers far greater cause for optimism, with fewer difficulties associated with their application. Indeed, current in vitro and in vivo projects indicate that there are some interesting developments on the scientific horizon which are likely, after some modifications and assurances regarding efficiency and safety, to be adopted in future clinical trials.

All of this means that, 60 years on from the first successful kidney transplant, it can be concluded that the greatest achievements in the field have been associated with the development of surgical techniques alongside planned and systemic immunosuppression. It can also be summarized, having observed developments within regenerative medicine and tissue engineering, that there are ongoing innovations which are likely to presage new milestones in the field of transplantology, helping to improve a number of procedures which are presently not as effective as they often promise to be.

\section{Conflict of interest}

The authors declare no conflict of interest.

\section{References}

1. Barry JM, Murray JE. The first human renal transplants. J Urol 2006; 176: 888-90.

2. Murray JE. The 50th anniversary of the first successful human organ transplant. Rev Invest Clin 2005; 57: 118-9.

3. Murray JE. The first successful organ transplants in man. J Am Coll Surg 2005; 200: 5-9.

4. Desai SP, Desai MS, Wood DN, Maddi R, Leeson S, Tilney NL. A semi-centennial report on the participants depicted in Joel Babb's portrait, 'the first successful kidney transplantation'. Am J Transplant 2007; 7: 1683-8.

5. Watson CJ, Dark JH. Organ transplantation: historical perspective and current practice. $\mathrm{Br} J$ Anaesth 2012; 108: i29-42.

6. Jones PD, Hayashi PH, Barritt S. Liver transplantation in 2013: challenges and controversies. Minerva Gastroenterol Dietol 2013; 59: 117-31.

7. Zarrinpar A, Busuttil RW. Liver transplantation: past, present and future. Nat Rev Gastroenterol Hepatol 2013; 10: 434-40.

8. Wegrzyn P, Popiolek M, Przybylowski P, et al. The risk of cholelithiasis in patients after heart transplantation. Arch Med Sci 2014; 10: 53-7.

9. Goel MC, Modlin CS, Mottoo AM, et al. Fate of donor kidney: laparoscopic versus open technique. J Urol 2004; 172: 2326-30.

10. Matheus WE, Reis LO, Ferreira U, et al. Kidney transplant anastomosis: internal or external iliac artery? Urol J 2009; 6: 260-6.

11. Machnicki G, Lentine KL, Salvalaggio PR, Burroughs TE, Brennan DC, Schnitzler MA. Kidney transplant Medi- 
care payments and length of stay: associations with comorbidities and organ quality. Arch Med Sci 2011; 7: 278-86.

12. Yuan H, Liu L, Zheng S, et al. The safety and efficacy of laparoscopic donor nephrectomy for renal transplantation: an updated meta-analysis. Transplant Proc 2013; 45: 65-76.

13. Gibbons N, Nicol D; CARI. The CARI guidelines. Surgical techniques in living donor nephrectomy. Nephrology (Carlton) 2010; 15: S88-95.

14. Chedid MF, Muthu C, Nyberg SL, et al. Living donor kidney transplantation using laparoscopically procured multiple renal artery kidneys and right kidneys. J Am Coll Surg 2013; 217: 144-52.

15. Litynski GS. Laparoscopy - the early attempts: spotlighting Georg Kelling and Hans Christian Jacobaeus. J Soc Laparoendosc Surgeons 1997; 1: 83-5.

16. Bhattacharya K. Kurt Semm: a laparoscopic crusader. J Minim Access Surg. 2007; 3: 35-6.

17. Reynolds W. The first laparoscopic cholecystectomy. JSLS 2001; 5: 89-94.

18. Ibrahim IN, Foley R, Tan L, et al. Long-term consequences of kidney donation. N Engl J Med 2009; 360: 459-69.

19. Clayman RV, Kavoussi LR, Soper NJ, et al. Laparoscopic nephrectomy: initial case report. J Urol 1991; 146: 278-82.

20. Kavoussi LR, Kerbl K, Capelouto CC, McDougall EM, Clayman RV. Laparoscopic nephrectomy for renal neoplasms. Urology 1993; 42: 603-9.

21. Nicholson ML, Veitch PS. Laparoscopic live-donor nephrectomy. Nephrol Dial Transplant 2000; 15: 1124-6.

22. Antcliffe D, Nanidis TG, Darzi AW, Tekkis PP, Papalois VE. A metaanalysis of mini-open versus standard open and laparoscopic living donor nephrectomy. Transplant Int 2009; 22: 463-74.

23. Nanidis TG, Antcliffe D, Kokkinos C, et al. Laparoscopic versus open live donor nephrectomy in renal transplantation: a meta-analysis. Ann Surg 2008; 247: 58-70.

24. Shokeir AA. Open versus laparoscopic live donor nephrectomy: a focus on the safety of donors and the need for a donor registry. J Urol 2007; 178: 1860-6.

25. Nicholson ML, Kaushik M, Lewis GR, et al. Randomized clinical trial of laparoscopic versus open donor nephrectomy. Br J Surg 2010; 97: 21-8.

26. Dolce CJ, Keller AK, Walters C, et al. Laparoscopic versus open live donor nephrectomy: outcomes analysis of 266 consecutive patients. Surg Endosc 2009; 23: 1564-8.

27. Halgrimson WR, Campsen J, Mandell MS, Kelly MA, Kam I, Zimmerman MA. Donor complications following laparoscopic compared to hand-assisted living donor nephrectomy: an analysis of the literature. J Transplant 2010; 2010: 825689.

28. Mioen G, Oven O, Oldaas H, Midtvedt K, Line PD. Morbidity and mortality in 1022 consecutive living donor nephrectomies: benefits of a living donor registry. Transplantation 2009; 88: 1273-9.

29. Harper JD, Breda A, Leppert JT, Veale JL, Gritsch HA, Schulam PG. Experience with 750 consecutive laparoscopic donor nephrectomies - is it time to use a standardized classification of complications? J Urol 2010; 183: 1941-6

30. Hamidi V, Andersen MH, Oyen O, Mathisen L, Fosse E, Kristiansen IS. Cost effectiveness of open versus laparoscopic living-donor nephrectomy. Transplantation 2009; 87: 831-8.

31. Kranenburg L, Weimar W. Incentives for living kidney donation: what does the public think? Transplantation 2008; 86: 500-1.
32. Schnitzler MA, Whiting JF, Brennan DC, et al. The expanded criteria donor dilemma in cadaveric renal transplantation. Transplantation 2003; 75: 1940-5.

33. Schweitzer EJ, Wilson J, Jacobs S, et al. Increased rates of donation with laparoscopic donor nephrectomy. Ann Surg 2000; 232: 392-400.

34. Gregorio SA, Rivas JG, Sánchez LC, et al. Laparoscopic ureteral reimplantation in a renal transplant. Cent European J Urol 2013; 66: 366-8.

35. Autorino R, Sosnowski R, De Sio M, Simone O, Khalifeh A, Kaouk JH. Laparo-endoscopic single-site surgery: recent advances in urology. Cent European J Urol 2012; 65: 204-11.

36. Lanfranco AR, Castellanos AE, Desai JP, Meyers WC. Robotic surgery: a current perspective. Ann Surg 2004; 239: 14-21.

37. Sánchez-Martín FM, Jiménez Schlegl P, Millán Rodriguez $F$, et al. History of robotics: from archytas of tarentum until Da Vinci robot. (Part II). Actas Urol Esp 2007; 31: 185-96.

38. Hoznek A, Zaki SK, Samadi DB, et al. Robotic assisted kidney transplantation: an initial experience. J Urol 2002; 167: 1604-6.

39. Kim SJ, Choi BJ, Lee SC. Overview of single-port laparoscopic surgery for colorectal cancers: past, present, and the future. World J Gastroenterol 2014; 20: 9971004.

40. Palep JH. Robotic assisted minimally invasive surgery. J Minim Access Surg 2009; 5: 1-7.

41. Horgan S, Vanuno D, Benedetti E. Early experience with robotically assisted laparoscopic donor nephrectomy. Surg Laparosc Endosc Percutan Tech 2002; 12: 64-70.

42. Paragi PR, Klaassen Z, Fletcher HS, et al. Vascular constraints in laparoscopic renal allograft: comparative analysis of multiple and single renal arteries in 976 laparoscopic donor nephrectomies. World J Surg 2011; 35: 2159-66.

43. Benedetti E, Shapiro R. Laparoscopic kidney transplantation - novel or novelty? Am J Transplant 2011; 11: 1121-2.

44. Boggi U, Vistoli F, Signori S, et al. Robotic renal transplantation: first European case. Transpl Int 2011; 24: 213-8.

45. Warren J, da Silva V, Caumartin Y, Luke PP. Robotic renal surgery: the future or a passing curiosity? Can Urol Assoc J 2009; 3: 231-40.

46. Apoznański W, Jankowski A. Laparoscopy and pediatric urology. Cent European J Urol 2014; 67: 112.

47. Ahmed K, Khan MS, Vats A, et al. Current status of robotic assisted pelvic surgery and future developments. Int J Surg 2009; 7: 431-40.

48. Alkan E, Canda AE, Turan M, Balbay MD. Simultaneous robot assisted laparoscopic radical nephroureterectomy; genital tract and paravaginal nerve sparing radical cystectomy; superextended lymph node dissection and intracorporeal Studer pouch reconstruction for bladder cancer: robotic hat-trick. Cent European J Urol 2014; 67: 257-60.

49. Giulianotti P, Gorodner V, Sbrana F, et al. Robotic transabdominal kidney transplantation in a morbidly obese patient. Am J Transplant 2010; 10: 1478-82.

50. Kaouk JH, Khalifeh A, Laydner H, et al. Transvaginal hybrid natural orifice transluminal surgery robotic donor nephrectomy: first clinical application. Urology 2012; 80: 1171-5.

51. Galvani CA, Garza U, Leeds M, et al. Single-incision robotic-assisted living donor nephrectomy: case re- 
port and description of surgical technique. Transpl Int 2012; 25: e89-92.

52. Oberholzer J, Giulianotti P, Danielson KK, et al. Minimally invasive robotic kidney transplantation for obese patients previously denied access to transplantation. Am J Transplant 2013; 13: 721-8.

53. Tzvetanov I, Bejarano-Pineda L, Giulianotti PC, et al. State of the art of robotic surgery in organ transplantation. World J Surg 2013; 37: 2791-9.

54. Dev HS, Sooriakumaran P, Stolzenburg JU, Anderson CJ. Is robotic technology facilitating the minimally invasive approach to partial nephrectomy? BJU Int 2012; 109: 760-8

55. Oberholzer J, Testa G, Sankary H, John E, Thielke J, Benedetti E. Kidney transplantation at the University of Illinois at Chicago from 1988-2004. Clin Transpl 2004: 143-9.

56. Tzvetanov I, Giulianotti PC, Bejarano-Pineda L, et al. Robotic-assisted kidney transplantation. Surg Clin North Am 2013; 93: 1309-23.

57. Santomauro M, Reina GA, Stroup SP, L'Esperance JO. Telementoring in robotic surgery. Curr Opin Urol 2013; 23: 141-5.

58. Challacombe B, Kandaswamy R, Dasgupta P, Mamode N. Telementoring facilitates independent hand-assisted laparoscopic living donor nephrectomy. Trans plant Proc 2005; 37: 613-6.

59. Barbash GI, Glied SA. New technology and health care costs: the case of robot-assisted surgery. N Engl J Med 2010; 363: 701-4.

60. Scales CD Jr, Jones PJ, Eisenstein EL, Preminger GM, Albala DM. Local cost structures and the economics of robot assisted radical prostatectomy. J Urol 2005; 174: 2323-9.

61. Juo YY, Hyder O, Haider AH, Camp M, Lidor A, Ahuja N. Is minimally invasive colon resection better than traditional approaches? First comprehensive national examination with propensity score matching. JAMA Surg 2014; 149: 177-84

62. Salman M, Bell T, Martin J, Bhuva K, Grim R, Ahuja V. Use, cost, complications, and mortality of robotic versus nonrobotic general surgery procedures based on a nationwide database. Am Surg 2013; 79: 553-60.

63. Lenihan JP Jr, Kovanda C, Seshadri-Kreaden U. What is the learning curve for robotic assisted gynecologic surgery? J Minim Invasive Gynecol 2008; 15: 589-94

64. He B, Musk GC, Mou L, Waneck GL, Delriviere L. Laparoscopic surgery for kidney orthotopic transplant in the pig model. JSLS 2013; 17: 126-31.

65. Small AC, Gainsburg DM, Mercado MA, Link RE, Hedican SP, Palese MA. Laparoscopic needle-retrieval device for improving quality of care in minimally invasive surgery. J Am Coll Surg 2013; 217: 400-5.

66. Friedman DC, Lendvay TS, Hannaford B. Instrument failures for the da Vinci Surgical System: a Food and Drug Administration MAUDE Database Study. Surg Endosc 2013; 27: 1503-8.

67. Manoucheri E, Fuchs-Weizman N, Cohen SL, Wang KC, Einarsson JI. MAUDE - analysis of robotic-assisted gynecologic surgery. J Minim Invasive Gynecol 2014; 21: 592-5.

68. Adamowicz J, Kowalczyk T, Drewa T. Tissue engineering of urinary bladder - current state of art and future perspectives. Cent European J Urol 2013; 66: 202-6.

69. Sullivan DC, Mirmalek-Sani SH, Deegan DB, et al. Decellularization methods of porcine kidneys for whole organ engineering using a high-throughput system. Biomaterials 2012; 33: 7756-64.
70. Orlando G, Farney AC, Iskandar SS, et al. Production and implantation of renal extracellular matrix scaffolds from porcine kidneys as a platform for renal bioengineering investigations. Ann Surg 2012; 256: 363-70.

71. Park KM, Woo HM. Porcine bioengineered scaffolds as new frontiers in regenerative medicine. Transplant Proc 2012; 44: 1146-50.

72. Song JJ, Guyette JP, Gilpin SE, Gonzalez G, Vacanti JP, Ott HC. Regeneration and experimental orthotopic transplantation of a bioengineered kidney. Nat Med 2013; 19: 646-51.

73. Nishikawa M, Yanagawa N, Kojima N, et al. Stepwise renal lineage differentiation of mouse embryonic stem cells tracing in vivo development. Biochem Biophys Res Commun 2012; 417: 897-902.

74. Ren X, Zhang J, Gong X, et al. Differentiation of murine embryonic stem cells toward renal lineages by conditioned medium from ureteric bud cells in vitro. Acta Biochim Biophys Sin (Shanghai) 2010; 42: 464-71.

75. Morizane R, Monkawa T, Itoh H. Differentiation of murine embryonic stem and induced pluripotent stem cells to renal lineage in vitro. Biochem Biophys Res Commun 2009; 390: 1334-9.

76. Kooreman NG, Wu JC. Tumorigenicity of pluripotent stem cells: biological insights from molecular imaging. J R Soc Interface 2010; 7: S753-63.

77. Tang C, Weissman IL, Drukker M. The safety of embryonic stem cell therapy relies on teratoma removal. Oncotarget 2012; 3: 7-8.

78. Singaravelu K, Padanilam BJ. In vitro differentiation of MSC into cells with a renal tubular epithelial-like phenotype. Ren Fail 2009; 31: 492-502.

79. Baer PC, Döring C, Hansmann ML, Schubert R, Geiger $\mathrm{H}$. New insights into epithelial differentiation of human adipose-derived stem cells. J Tissue Eng Regen Med 2011; 7: 271-8.

80. Perin L, Giuliani S, Jin D, et al. Renal differentiation of amniotic fluid stem cells. Cell Prolif 2007; 40: 936-48.

81. Lanza RP, Chung HY, Yoo JJ, et al. Generation of histocompatibile tissues using nuclear transplantation. Nat Biotechnol 2002; 20: 689-96.

82. Humes HD, Weitzel WF, Bartlett RH, et al. Initial clinical results of the bioartificial kidney containing human cells in ICU patients with acute renal failure. Kidney Int 2004; 66: 1578-88.

83. Tasnim F, Deng R, Hu M, et al. Achievements and challenges in bioartificial kidney development. Fibrogenesis Tissue Repair 2010; 3: 14.

84. Nowacki M, Kloskowski T, Pokrywczyńska M, et al. Is regenerative medicine a new hope for kidney replacement? J Artif Organs 2014; 17: 123-34.

85. Oo ZY, Deng R, Hu M, et al. The performance of primary human renal cells in hollow fiber bioreactors for bioartificial kidneys. Biomaterials 2011; 32: 8806-15.

86. Brodie JC, Humes HD. Stem cell approaches for the treatment of renal failure. Pharmacol Rev 2005; 57: 299-313.

87. Sciancalepore AG, Sallustio F, Girardo S, et al. A bioartificial renal tubule device embedding human renal stem/progenitor cells. PLoS One 2014; 9: e87496.

88. Salvatori M, Peloso A, Katari R, Orlando G. Regeneration and bioengineering of the kidney: current status and future challenges. Curr Urol Rep 2014; 15: 379.

89. Kim S, Fissell WH, Humes DH, Roy S. Current strategies and challenges in engineering of bioartificial kidney. Front Biosci (Elite Ed) 2015; 7: 248-62. 
90. Rosines E, Johkura K, Zhang X, et al. Constructing kidney-like tissues from cells based on programs for organ development: toward a method of in vitro tissue engineering of the kidney. Tissue Eng Part A 2010; 16: 2441-55.

91. Usui Jl, Kobayashi T, Yamaguchi T, Knisely AS, Nishinakamura R, Nakauchi H. Generation of kidney from pluripotent stem cells via blastocyst complementation. Am J Pathol 2012; 180: 2417-26.

92. Rosenberg ME, Gupta S. Stem cells and the kidney: where do we go from here? J Am Soc Nephrol 2007; 18: 3018-20.

93. Mazor M, Lespessailles E, Coursier R, Daniellou R, Best TM, Toumi H. Mesenchymal stem-cell potential in cartilage repair: an update. J Cell Mol Med 2014; 18: 2340-50.

94. Skóra J, Pupka A, Janczak D, Mastalerz-Migas, J. Garcarek. Combined autologous bone marrow mononuclear cell and gene therapy as the last resort for patients with critical limb ischemia. Arch Med Sci 2015 ; 11: 325-31.

95. Nowacki M, Pietkun K, Pokrywczyńska M, et al. Filling effects, persistence, and safety of dermal fillers formulated with stem cells in an animal model. Aesthet Surg J 2014; 34: 1261-9.

96. Kloskowski T, Pokrywczyńska M, Drewa T. Artificial urinary konduit construction Rusing tissue engineering methods. Cent European J Urol 2015; 68: 109-14.

97. Uzarski JS, Xia Y, Belmonte JC, Wertheim JA. New strategies in kidney regeneration and tissue engineering. Curr Opin Nephrol Hypertens 2014; 23: 399-405.

98. Bianchi F, Sala E, Donadei C, Capelli I, La Manna G. Potential advantages of acute kidney injury management by mesenchymal stem cells. World J Stem Cells 2014; 6: 644-50.

99. Rosenberg ME. Cell-based therapies in kidney disease. Kidney Int Suppl (2011) 2013; 3: 364-7.

100. Morigi M, Benigni A. Mesenchymal stem cells and kidney repair. Nephrol Dial Transplant 2013; 28: 788-93.

101. Tögel FE, Westenfelder C. Kidney protection and regeneration following acute injury: progress through stem cell therapy. Am J Kidney Dis 2012; 60: 1012-22.

102. Tumlin J, Wali R, Williams W, et al. Efficacy and safety of renal tubule cell therapy for acute renal failure. J Am Soc Nephrol 2008; 19: 1034-40.

103. Joosten SA, Sijpkens YW, van Kooten C, Paul LC. Chronic renal allograft rejection: pathophysiologic considerations. Kidney Int 2005; 68: 1-13.

104. Kamińska J, Głyda M, Sobiak J, Chrzanowska M. Pharmacokinetics of mycophenolic acid and its phenyl glucuronide metabolite in kidney transplant recipients with renal impairment. Arch Med Sci 2012; 8: 88-96.

105. Mas VR, Mueller TF, Archer KJ, Maluf DG. Identifying biomarkers as diagnostic tools in kidney transplantation. Expert Rev Mol Diagn 2011; 11: 183-96.

106. Domanski L, Kłoda K, Pawlik A, et al. Correlation between ICAM1 and VCAM1 gene polymorphisms and histopathological changes in kidney allograft biopsies. Arch Med Sci 2013; 9: 276-82.

107. Legendre C, Kreis H. A Tribute to Jean Hamburger's contribution to organ transplantation. Am J Transplant 2010; 10: 2392-5.

108. Barbara PG. "Advice to the medical students in my service": the rediscovery of a golden book by Jean Hamburger, father of nephrology and of medical humanities. Philos Ethics Humanit Med 2013; 8: 2.
109. Kuss R, Legrain M, Mathe G, Nedey R, Camey M. Homologous human kidney transplantation. Postgrad Med J 1962; 38: 528-31.

110. Ohshima S, Kinukawa T, Matsuura O, et al. Thoracic duct drainage pretreatment and low dose cyclosporine and low dose steroid immunosuppressive treatment in living related kidney transplantation. Nihon Hinyokika Gakkai Zasshi 1990; 81: 225-9.

111. Robinson JL, Christian CL. 6-mercaptopurine in immunological responsiveness. Nature 1960; 187: 796-7.

112. Elion GB. The George Hitchings and Gertrude Elion Lecture. The pharmacology of azathioprine. Ann N Y Acad Sci 1993; 685: 400-7.

113. Korelitz BI. A history of immunosuppressive drugs in the treatment of inflammatory bowel disease: origins at The Mount Sinai Hospital. Mt Sinai J Med 2000; 67: 214-26.

114. Kamińska J, Sobiak J, Głyda M, et al. Effect of clinical condition and mycophenolate mofetil on plasma retinol, alpha-tocopherol and beta-carotene in renal transplant recipients. Arch Med Sci 2012; 8: 256-62.

115. Rush D, Nickerson P, Gough J, et al. Beneficial effects of treatment of early subclinical rejection: a randomized study. J Am Soc Nephrob 1998; 9: 2129-34.

116. Perico N, Ruggenenti P, Gotti E, et al. In renal transplantation blood cyclosporine levels soon after surgery act as a major determinant of rejection: insights from the MY.S.S. trial. Kidney Int 2004; 65: 1084-90.

117. Gullestad L, Iversen M, Mortensen SA, et al. Everolimus with reduced calcineurin inhibitor in thoracic transplant recipients with renal dysfunction: a multicenter, randomized trial. Transplantation 2010; 89: 864-72.

118. Apuri S, Carlin K, Bass E, Nguyen PT, Greene JN. Tacrolimus associated posterior reversible encephalopathy syndrome - a case series and review. Mediterr J Hematol Infect Dis 2014; 6: e2014014.

119. Emiroglu R, Ayvaz I, Moray G, Karakayali H, Haberal M. Tacrolimus-related neurologic and renal complications in liver transplantation: a single-center experience. Transplant Proc 2006; 38: 619-21.

120. Lindholm A, Dahlqvist R, Groth GG, Sjoqvist F. A prospective study of cyclosporine concentration in relation to its therapeutic effect and toxicity after renal transplantation. Br J Clin Pharmac 1990; 30: 443-52.

121. Shapiro R, Jordan M, Scantlebury V, et al. FK 506 in clinical kidney transplantation. Transplant Proc 1991; 23: 3065-7.

122. Montagnino G, Tarantino A, Segoloni GP, et al. Longterm results of a randomized study comparing three immunosuppressive schedules with cyclosporine in cadaveric kidney transplantation. J Am Soc Nephrol 2001; 12: 2163-9.

123. Kwon O, Cho JH, Choi JY, et al. Long-term outcome of azathioprine versus mycophenolate mofetil in cyclosporine-based immunosuppression in kidney transplantation: 10 years of experience at a single center. Transplant Proc 2013; 45: 1487-90.

124. Habib SL. Mechanism of activation of AMPK and upregulation of OGG1 by rapamycin in cancer cells. Oncotarget 2011; 2: 958-9.

125. Pascual J. The use of everolimus in renal-transplant patients. Int J Nephrol Renovasc Dis 2009; 2: 9-21.

126. Das U, Dakshinamurty KV. Safety and efficacy of everolimus in chronic allograft nephropathy. Saudi J Kidney Dis Transpl 2013; 24: 910-6.

127. Wiesel M, Carl S. A placebo controlled study of mycophenolate mofetil used in combination with cyclospo- 
rine and corticosteroids for the prevention of acute rejection in renal allograft recipients: 1-year results. The European Mycophenolate Mofetil Cooperative Study Group. J Urol 1998; 159: 28-33.

128. Ishida K, Ito S, Tsuchiya T, Imanishi Y, Deguchi T. Clinical experience with once-daily tacrolimus in de novo kidney transplant recipients from living donors in Japan: 1-year follow up. Cent European J Urol 2013; 66: 344-9.

129. Ciszek M. Once- versus twice-daily tacrolimus: are the formulations equivalent? Cent European J Urol 2013; 66: 350-1.

130. Patschan D, Kribben A, Pietruck F, et al. OKT3 therapy in addition to tacrolimus is associated with improved long-term function in patients with steroid refractory renal allograft rejection. Nephron Clin Pract 2006; 103: c94-9.

131. Deodhar SD, Konomi K, Nakamoto S, Kuruvila KC. Clinical experience with antilymphocyte globulin (ALG) in renal transplantation. Transplant Proc 1971; 3: 758-61.

132. Song $\mathrm{YH}$, Huh $\mathrm{KH}$, Kim YS, et al. Impact of pretransplant rituximab induction on highly sensitized kidney recipients: comparison with non-rituximab group. J Korean Surg Soc 2012; 82: 335-9.

133. Maes BD, Vanrenterghem YF. Anti-interleukin-2 receptor monoclonal antibodies in renal transplantation. Nephrol Dial Transplant 1999; 14: 2824-6.

134. Saghafi H, Rahbar K, Nobakht Haghighi A, Qoreishi M, Safdari F. Efficacy of anti-interleukin-2 receptor antibody (daclizumab) in reducing the incidence of acute rejection after renal transplantation. Nephrourol Mon 2012; 4: 475-7.

135. Gundlapalli S, Rathi M, Kohli HS, et al. Efficacy of basiliximab induction in poorly matched living donor renal transplantation. Indian J Nephrol 2013; 23: 409-12.

136. Takahashi K, Saito K. ABO-incompatible kidney transplantation. Transplant Rev (Orlando) 2013; 27: 1-8.

137. Gupta PN, Pokhariyal S, Bansal S, et al. Renal transplantation across ABO barrier. Indian J Nephrol 2013; 23: 214-6.

138. Djamali A, Samaniego M, Muth B, et al. Medical care of kidney transplant recipients after the first posttransplant year. Clin J Am Soc Nephrol 2006; 1: 623-40.

139. Briggs JD. Causes of death after renal transplantation. Nephrol Dial Transplant 2001; 16: 1545-9.

140. Thompson JS, Thacker LR 2nd, Krishnan G. Human leukocyte antigens $D R$ and $A B$ and kidney retransplantation. Transplantation 2003; 75: 718-23.

141. Jansen J. Jon Van Rood: pioneer at the crossroad of human leukocyte antigens and transplantation. Transfus Med Rev 2007; 21: 159-63.

142. Raeisi D, Payandeh M, Madani SH, Zare ME, Kansestani AN, Hashemian AH. Kaposi's sarcoma after kidney transplantation: a 21-years experience. Int J Hematol Oncol Stem Cell Res 2013; 7: 29-33.

143. First MR, Dhadda S, Croy R, Holman J, Fitzsimmons WE. New-onset diabetes after transplantation (NODAT): an evaluation of definitions in clinical trials. Transplantation 2013; 96: 58-64.

144. Pham PT, Pham PM, Pham SV, Pham PA, Pham PC. New onset diabetes after transplantation (NODAT): an overview. Diabetes Metab Syndr Obes 2011; 4: 175-86.

145. Hap K, Madziarska K, Hap W, Mazanowska O. Phenotypic risk factors for new-onset diabetes mellitus (NODAT) in renal transplant recipients. Postepy Hig Med Dosw (Online) 2014; 68: 1347-51.

146. Mangray M, Vella JP. Hypertension after kidney transplant. Am J Kidney Dis 2011; 57: 331-41.
147. Cooper JE, Wiseman AC. Novel immunosuppressive agents in kidney transplantation. Clin Nephrol 2010; 73: 333-43.

148. Gregory CR, Kyles AE, Bernsteen L, et al. Compared with cyclosporine, ISATX247 significantly prolongs renal-allograft survival in a nonhuman primate model. Transplantation 2004; 78: 681-5.

149. Bigaud M, Wieczorek G, Beerli C, et al. (AEB071) alone and in combination with cyclosporine $\mathrm{A}$ prolongs survival times of non-human primate recipients of life-supporting kidney allografts. Transplantation 2012; 93: 156-64.

150. Russ GR, Tedesco-Silva H, Kuypers DR, et al. Efficacy of sotrastaurin plus tacrolimus after de novo kidney transplantation: randomized, phase II trial results. Am J Transplant 2013; 13: 1746-56.

151. Wojciechowski D, Vincenti F. Belatacept in kidney transplantation. Curr Opin Organ Transplant 2012; 17: 640-7.

152. Wojciechowski D, Vincenti F. Belatacept for prevention of acute rejection in adult patients who have had a kidney transplant: an update. Biologics 2012; 6: 385-93.

153. Lo DJ, Anderson DJ, Weaver TA, et al. Belatacept and sirolimus prolong nonhuman primate renal allograft survival without a requirement for memory $T$ cell depletion. Am J Transplant 2013; 13: 320-8.

154. Vincentia F, Tedesco Silvab H, Busquec S, et al. Randomized phase $2 \mathrm{~b}$ trial of tofacitinib (CP-690,550) in de novo kidney transplant patients: efficacy, renal function and safety at 1 year. Am J Transplant 2012; 12: 2446-56.

155. Zand MS. Tofacitinab in renal transplantation. Transplant Rev (Orlando) 2013; 27: 85-9.

156. Rostaing L, Charpentier B, Glyda M, et al. Alefacept combined with tacrolimus, mycophenolate mofetil and steroids in de novo kidney transplantation: a randomized controlled trial. Am J Transplant 2013; 13: 1724-33.

157. Bechtel M, Sanders C, Bechtel A. Neurological complications of biologic therapy in psoriasis: a review. J Clin Aesthet Dermatol 2009; 2: 27-32.

158. Berger JR, Houff SA, Major EO. Monoclonal antibodies and progressive multifocal leukoencephalopathy. MAbs 2009; 1: 583-9.

159. Schwab N, Ulzheimer JC, et al. Fatal PML associated with efalizumab therapy: insights into integrin alphaLbeta2 in JC virus control. Neurology 2012; 78: 458-67.

160. Zaza G, Tomei P, Granata S, Boschiero L, Lupo A. Monoclonal antibody therapy and renal transplantation: focus on adverse effects. Toxins 2014; 6: 869-91.

161. Stegalla MD, Diwana T, Raghavaiaha S, et al. Terminal complement inhibition decreases antibody-mediated rejection in sensitized renal transplant recipients. Am J Transplant 2011; 11: 2405-13.

162. Legendre C, Sberro-Soussan R, Zuber J, et al. Eculizum$\mathrm{ab}$ in renal transplantation. Transplant Rev (Orlando) 2013; 27: 90-2.

163. Cicora F, Paz M, Mos F, Roberti J. Use of bortezomib to treat anti-HLA antibodies in renal transplant patients: a single-center experience. Transpl Immunol 2013; 29 7-10.

164. Wong W, Lee RA, Saidman SL, Smith RN, Zorn E. Bortezomib in kidney transplant recipients with antibody mediated rejection: three case reports. Clin Transpl 2009: 401-5.

165. Mazuecos A, Rodriguez Benot A, Moreno A, et al. Renal replacement therapy in patients with HIV infection in 
a European Region: outcomes following renal transplantation. Transplant Proc 2012; 44: 2053-6.

166. Landin L, Rodriguez-Perez JC, Garcia-Bello MA, et al. Kidney transplants in HIV-positive recipients under HAART. A comprehensive review and meta-analysis of 12 series. Nephrol Dial Transplant 2010; 25: 3106-15.

167. Ciuffreda D, Pantaleo G, Pascual M. Effects of immunosuppressive drugs on HIV infection: implications for solid-organ transplantation. Transpl Int 2007; 20: 649-58.

168. Huang CA, Fuchimoto Y, Scheier-Dolberg R, Murphy MC, Neville DM, Sachs DH. Stable mixed chimerism and tolerance using a nonmyeloablative preparative regimen in a large-animal model. J Clin Invest 2000; 105: 173-81.

169. Seifert M, Stolk M, Polenz D, Volk HD. Detrimental effects of rat mesenchymal stromal cell pre-treatment in a model of acute kidney rejection. Front Immunol 2012; 3: 202.

170. Wu D, Qi G, Wang X, et al. Hematopoietic stem cell transplantation induces immunologic tolerance in renal transplant patients via modulation of inflammatory and repair processes. J Transl Med 2012; 10: 182.

171. Kawai T, Sachs DH, Sprangers B, et al. Long-term results in recipients of combined HLA-mismatched kidney and bone marrow transplantation without maintenance immunosuppression. Am J Transplant 2014; 14: 1599-611.

172. Leventhal J, Abecassis M, Miller J, et al. Chimerism and tolerance without GVHD or engraftment syndrome in HLA-mismatched combined kidney and hematopoietic stem cell transplantation. Sci Transl Med 2012; 4: $124 \mathrm{ra} 28$.

173. Tan J, Wu W, Xu X, et al. Induction therapy with autologous mesenchymal stem cells in living-related kidney transplants. JAMA 2012; 307: 1169-77.

174. Reinders ME, de Fijter JW, Roelofs $\mathrm{H}$, et al. Autologous bone marrow-derived mesenchymal stromal cells for the treatment of allograft rejection after renal transplantation: results of a phase I study. Stem Cells Transl Med 2013; 2: 107-11. 